\title{
MONITORING OF FOOD SECURITY AT REGIONAL LEVEL
}

\author{
Olena Kotykova ${ }^{1}$, Mykola Babych ${ }^{2}$, Semenchuk Iryna $^{3}$ \\ ${ }^{I}$ Doctor of Economic Sciences, Professor, Business Economy Department, Mykolaiv \\ National Agrarian University, Mykolaiv, Ukraine. \\ Tel. +38 (099) 29303 63, E-mail: eikotikova7@gmail.com \\ ${ }^{2}$ Doctor of Economic Sciences, Associate Professor, Department of Accounting and \\ Economic Analysis, Admiral Makarov National University of Shipbuilding, Mykolaiv, Ukraine. \\ Tel. +38 (067) 51800 98, E-mail: babychnnn@gmail.com \\ ${ }^{3}$ Candidate of Economic Sciences, Associate professor, Petro Mohyla Black \\ Sea National University. 54003, Mykolaiv, Ukraine. \\ Tel.+38(067) 11584 03.E-mail: irina_semenchuk1@chmnu.edu.ua
}

Received 0410 2019; accepted 20122019

Ukraine does not have a methodological approach to the food security monitoring, including the regional level, which should meet the criteria and dimensions of the GSDs-2030.

The purpose of the article: to identify problems in the field of food security in each particular region based on to carry out an integral assessment of the of food security in accordance with the criteria and measurements of the GSDs -2030.

The authors developed a methodological approach to the food security monitoring and evaluation at the regional level, which includes a rating assessment of the food supply of the regions by the 9 indicators over the last five years (on the average and in the dynamics). Appropriate calculations and proposals for solving the identified problems in the field of food security in each particular region were made.

Keywords: consumption, food security, index, indicator, production, rating, regional level. JEL Codes: C13, O18.

\section{Introduction}

The formation of a strategy for regional development requires an objective monitoring of all components of socio-economic and environmental policy of the region. In accordance with the goals of the sustainable development of Ukraine-2030, ensuring food security is a priority task.

Although the 17 GSDs are not legally binding, governments are expected to take responsibility and create the national conditions for their achievement. Countries have a primary responsibility for the running and analysis of the achievement of these goals, which requires high-quality, accessible and timely data collection. Regional monitoring and analysis will be based on national analyzes and facilitate further activities and analysis on the global level (On Global ..., 2018).

Copyright (C) 2019 The Authors. Published by Vytautas Magnus University. This is an open-access article distributed under the terms of the Creative Commons Attribution-NonCommercial 4.0 (CC BY-NC 4.0) license, which permits unrestricted use, distribution, and reproduction in any medium, provided the original author and source are credited. The material cannot be used for commercial purposes. 
The researches of many scientists are devoted to the study of the integral assessment of the food security management on the regional level. In particular, the criteria and indicators for food security on the regional level are investigated by Bitov and Gasuha (2013); the system of regional aspects and peculiarities of providing food security was highlighted by Dzyuba (2013), Orlenko (2013); Providing food security in conjunction with different production spheres and industries is studied by Shebanina (2018), Babych (2018); Problems and mechanisms of food security at the regional level are investigated by Bodak (2014), Kozak (2014) etc. At the same time, researchers have paid much less attention to assessing the food security management result on the regional level.

Thus, an assessment of the food security of certain regions of Ukraine was carried out in the works of Nikishina (2012), Volchenko (2015), Kondra (2012), Ternavskaya (2010). In the studies of Stavitsky and Prokopenko (2014), Piskunova and Osipova (2015) are highlighted various approaches to the integral assessment of the food security in the regions. However, the methodology proposed by the authors only partially reflects the task of the GSD-2030, and therefore the obtained results are not relevant to the regional sustainable development policy.

The problem of the study. Ukraine does not have a methodological approach to the food security monitoring, including the regional level, which should meet the criteria and dimensions of the GSDs-2030.

The purpose of the study. To identify problems in the field of food security in each particular region based on to carry out an integral assessment of the of food security management result on the regional level in accordance with the criteria and measurements of the GSDs -2030 .

The object of the study is the food security at the regional level.

The research subject includes the methodological approach to the food security monitoring and evaluation at the regional level and indicators calculating the rating.

Research methods. The Ministry of Economic Development and Trade of Ukraine initiated and coordinated the inclusive process of discussing the GSDs. More than 800 leading specialists in the thematic areas of the GSDs were involved in the open process of establishing the national tasks of the GSDs, which ensured the objectivity of the assessments. Representatives of ministries and agencies, government agencies, UN agencies in Ukraine, international organizations, the business community, expert community, public organizations (primarily those representing the interests of the most vulnerable groups) and civil society represented the proposals for sustainable development of Ukraine.

The result of the inclusive process of adaptation of the GSDs for Ukraine was the National Report, which provides guidance on Ukraine's development until 2030 (Sustainable ..., 2017). The report presents the results of the adaptation of 17 global GSDs taking into account the specifics of national development (On Global ..., 2018). In particular, the second goal, "Overcoming hunger, agricultural development", proposed 9 indicators for monitoring and assessing food security at the national level. 
For monitoring and assessing the food security at the regional level both the system of indicators and the method of their calculation need to be modified taking into account the main criterion for achieving the food security in the region.

The conducted researches of the scientific and theoretical principles of the food security formation and its problems in Ukraine allow as a criterion for achieving food security at the regional level to determine such a determinant - the creation of the sustainable food systems.

In our opinion, the stability of the food system equally reflects both the number of products produced and the number of consumed products. At the same time, the comparison of these indicators reflects the economic availability of products and the degree of satisfaction of human needs in the nutrition. Another important criterion for the sustainability of the food system is the physical availability of food in a certain territory and its storage in places that provide the required level of product quality (Kotykova, 2019).

Taking into account the above, we included in the partial indicators of the monitoring and assessment of the food security at the regional level the following indicators:

- the ratio of volumes of production and consumption of meat and meat products, milk and dairy products, eggs, oils, fruits, berries and grapes, vegetables and food melons (per capita, \%);

- the ratio of the number of trade places in food markets to the total population by regions of Ukraine (one per 10,000 people);

- the ratio of the number of retail stores to the total population by regions of Ukraine ( $\mathrm{m}^{2}$ per 1000 people).

Two basic positions were the methodological basis for the selection of partial indicators of integrated performance of the food security management at the regional level:

- the compliance of certain partial indicators with the criteria for assessing the realization of GSDs-2030 at the regional level;

- the relevance and informativeness of each partial indicator.

The schematically proposed methodological approach to monitoring and assessing food security at the regional level is shown in Figure 1. 


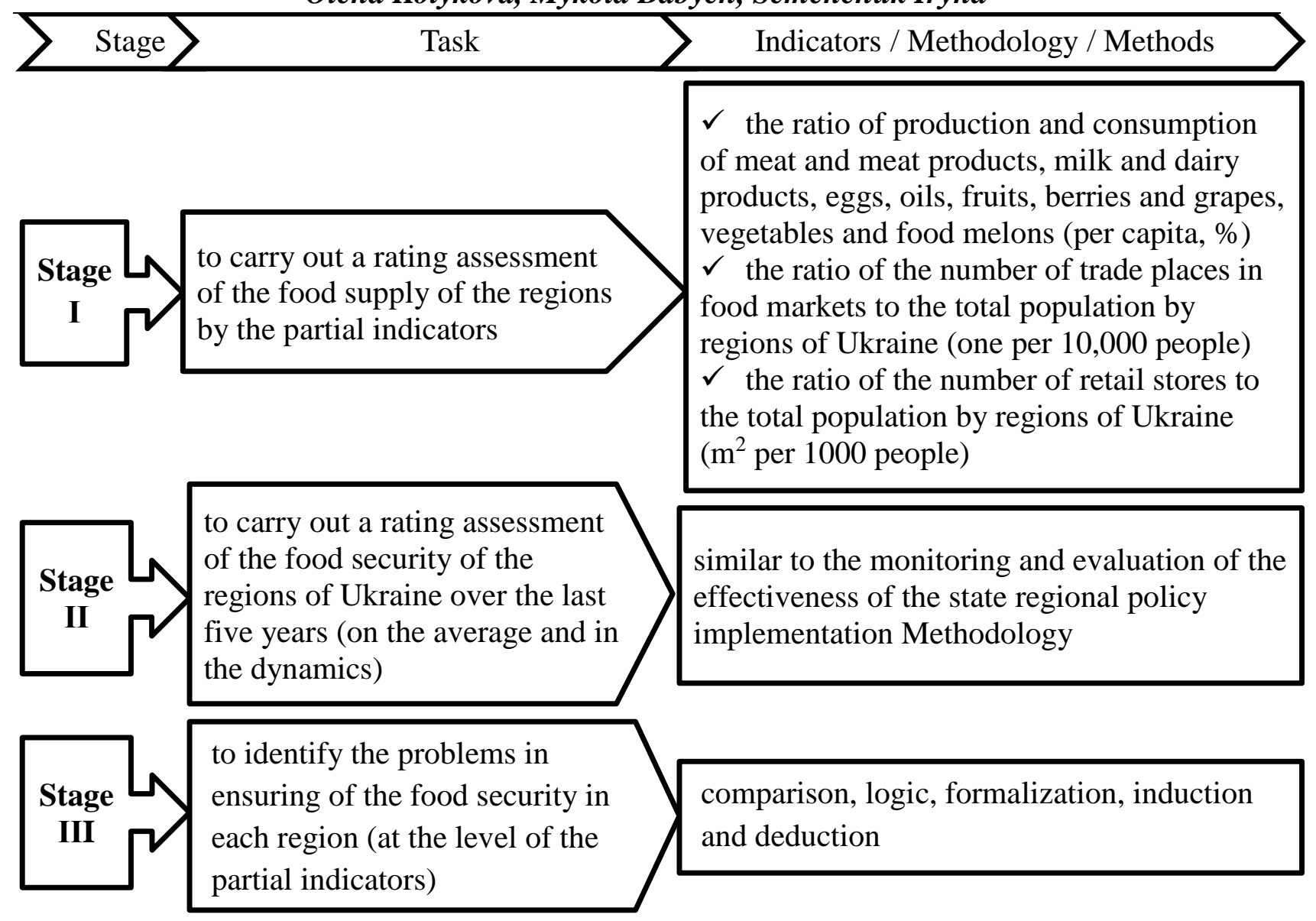

Figure 1. Methodological approach to the food security monitoring and evaluation at the regional level

The integrated assessment of the food security at the regional level involves making calculations of the regional rating (ranking) of each indicator and calculating the overall rating in general for all indicators, in the same way as the Methodology for monitoring and evaluating the effectiveness of the implementation of the state regional policy. It should be noted that in accordance with the Methodology for monitoring and evaluating the effectiveness of the implementation of the state regional policy, the final rating is conducted in all areas; in our study, the final rating assessment is carried out in all the years studied: from 2012 to 2016 inclusive and based on the official data of the State Statistics Service of Ukraine.

\section{Research results and discussion}

The ratio of production and consumption of meat and meat products per capita by regions of Ukraine. According to the calculations, only there is no shortage of production per capita in relation to consumption in 5 regions of 24 during the investigated period: Volyn, Dnipropetrovsk, Kyiv, Cherkasy and Chernivtsi. At the same time there is a constant shortage of production volumes as compared to its consumption by the population in Zhytomyr, Zaporizhzhya, Mykolayiv, Sumy, Kharkiv and Chernihiv regions. Also if in these regions there is a positive dynamics of growth of the indicator, then in Donetsk, Zakarpattya, Zaporizhzhya, Lugansk, 
Odesa and Kherson regions the deficit is only increasing over the years. The critical level of self-sufficiency in the region by products (below 30\%) was observed in Lugansk region in 2015 and 2016.

The ratio of production and consumption of milk and dairy products per capita by regions of Ukraine. According to the data, one hundred percent level of selfsufficiency by products is established only in 2 regions of 24 - Poltava and Cherkasy regions. At the same time, no positive dynamics of the indicator is established in any region. It should also be noted that the significant reduction of the indicator occurred in 2013, and since then only the Vinnytsya, Poltava, Rivne, Sumy, Khmelnytsky, Cherkasy and Chernihiv regions have improved their positions. The critical level of self-sufficiency of the region's products during the years 2013-2016 was observed in the vast majority of regions of Ukraine: Dnipropetrovsk, Donetsk, Zakarpattya, Zaporizhzhya, Ivano-Frankivsk, Kirovograd, Lugansk, Lviv, Mykolayiv, Odesa, Rivne, Ternopil, Kherson and Chernivtsi regions.

The ratio of production and consumption of eggs per person by regions of Ukraine. The level of self-sufficiency of Ukrainian regions relative to the production and consumption of eggs per person is considerably better: in only 8 out of 24 regions during the investigated period the deficit of production per capita in relation to consumption was established (Volyn, Dnipropetrovsk, Donetsk, Lugansk, Lviv, Mykolayiv, Odesa and Kharkiv regions). Among the latter, the Volyn and Odesa regions where the ratio of egg production and consumption per person increased in 2012-2016, while the rest of the deficit areas further deepened it even more during the period under the study. The critical level of self-sufficiency of the region by products was observed in Lugansk region in 2015 and 2016.

The ratio of production and consumption of oil per person by regions of Ukraine. Oil, relative to other food products, is rather specific: it is already finished products that need to be processed, as opposed to eggs, fruits, potatoes and other types of products; needs more capital investment for industrial production, comparatively, for example, with meat and milk; consumed in much smaller volumes, which constrains the development of this sphere in households of the population. On the other hand, oil is among the top ten export-oriented products, which determines the variability in the distribution of enterprises for its production in the regions of Ukraine.

Thus, according to the calculated data, it is difficult to explain the rapid growth of the ratio of production and consumption of oil per person in Kherson region - from 1.3 in $2012-2015$ to $1572.7 \%$ in 2016 . It is known that in this region there are at least two major oil producing companies - Chumak and KAISA OIL. However, both companies have been long engaged in the production of these products, indicating some company manipulation of the official place of production or official registration. It should also be noted that it is the large companies that are the overwhelming majority in this field of activity to take advantage of their right not to provide statistical information, as evidenced by the data (their absence) of the Volyn, Zaporizhzhya and Poltava regions, and in 2016 the producers of Ivano-Frankivsk, 
Kyiv, Lviv, Rivne, Ternopil, Khmelnytsky and Chernivtsi regions. Among those areas where official data on insufficient level of self-sufficiency of products is installed in Donetsk, Zhytomyr and Sumy regions. Vinnytsya, Zakarpattya, Kirovograd, Mykolayiv and Kherson regions produce more products than it is necessary to ensure the rational consumption.

The ratio of production and consumption of fruits, berries and grapes per person by regions of Ukraine. Unlike already considered products, the production of fruits, berries and grapes requires certain natural and climatic conditions during cultivation and requires more attention to the conditions of storage of products, since the vast majority of it is sold in an unprocessed form. Therefore, it is quite understandable that only in 10 regions of 24 during the investigated period there is no shortage of production per capita in relation to consumption: Vinnytsya, Zakarpattya, Mykolayiv, Odesa, Poltava, Rivne, Ternopil, Kherson, Khmelnytsky and Chernivtsi. At the same time, it should be noted that only in three of the regions (Dnipropetrovsk, Ivano-Frankivsk and Kirovograd regions), which have insufficient production in relation to rational consumption norms, the dynamics of the indicator is negative. At the same time, the critical level of self-sufficiency in the region by products has not been recorded in any of the regions.

The ratio of production and consumption of potatoes per capita by regions of Ukraine. Potatoes are a traditional type of product for consumers in all regions of the country and are relatively unpretentious in terms of technology and growing conditions, which makes the product accessible to virtually everyone in all areas. The deficit of production in relation to rational consumption standards is established only in Dnipropetrovsk, Donetsk, Zaporizhzhya, Lugansk and Odessa regions.

The critical level of self-sufficiency of the region by products was recorded in the Donetsk region in 2015 and 2016. In other areas, the level of self-sufficiency of products significantly exceeds the level of rational consumption: in some areas the rate reaches the level of 500\% and above (Volyn, Rivne, Sumy, Ternopil and Chernihiv regions). At the same time, a significant decrease in the indicator in the dynamics of Zakarpattya (53.5\%), Rivne (65.3\%), Ternopil (67.3\%) and Chernihiv $(149.4 \%)$ regions should be noted.

The ratio of volumes of production and consumption of vegetables and food melons per one person in the regions of Ukraine. Vegetables and food-grade melons are similar in terms of the technology of production of prunes, berries and grapes, but, unlike the latter, vegetables and melons are the smallest indicator of the number of regions with a shortage of products: only Donetsk, Lugansk and Ivano-Frankivsk regions. At the same time, in the Ivano-Frankivsk region, the indicator dynamics is positive.

The highest level of self-sufficiency was found in the Kherson region $832.3 \%$, which fully corresponds to the specialization of the region for the production of vegetables and melons. At the same time, in the Kherson region, the highest growth rate of the indicator is 44.0. etc. It is also clear that there is a significant decrease in the rate of growth of the indicator in Lugansk and Donetsk regions -32.3 and $42.0 \%$. 
The critical level of self-sufficiency in the region has not been recorded in any of the regions, but the level of production and consumption of vegetables and food crops per person in the Donetsk region is close to the critical one - 36.5\% in 2016.

The ratio of the amount of retail outlets to the total population by regions of Ukraine. Traditionally, food markets for Ukrainians remain the main place of purchase of food. The highest level of trade turnover in food markets to the total population was established in Dnipropetrovsk, Zaporizhzhia, Lviv, Poltava, Kharkiv and Chernivtsi regions; the lowest is in Vinnytsya, Zhytomyr, Sumy, Ternopil, Khmelnytsky and Chernihiv regions.

In relation to 2012, in 2016, a significant increase in the ratio of the number of retail outlets to food markets to the total population occurred in the Kirovograd, Mykolayiv and Ternopil regions; the reduction is in the Donetsk, Lugansk and Khmelnytsky regions.

The ratio of retail store retail space to total population by region of Ukraine. In other equal conditions, the growth of the indicator of the ratio of retail store retail sales to total population should contribute to an increase in physical availability to food. Among the regions of Ukraine in 2016, the highest level of the indicator was established in the Dnipropetrovsk, Kyiv, Odesa and Kharkiv regions; the lowest is in Donetsk and Lugansk regions.

In relation to the year 2012, in 2016, a significant increase in the ratio of the retail space retail store to the total population was observed in Dnipropetrovsk, Zakarpattya, Kyiv, Kirovograd, Lviv, Odesa, Kharkiv, Kherson, Khmelnytsky and Chernivtsi regions; reduction - in the Donetsk and Lugansk regions.

According to the formal logic, an increase in the ratio of the number of retail outlets to the food markets and retail space retail stores to the total population should lead not only to increase the level of physical availability of food, but also to increase the level of its economic availability, as competition increases.

At the same time, according to the calculations, the high level of supply of goods by retail outlets in the food markets and trading areas of retail stores is not a guarantee of economic and physical access of the population of the region to food.

Thus, in 2012-2013 and 2014-2016, the first place among the regions of Ukraine in terms of the number of trade places in food markets to the total population took Lugansk and Chernivtsi regions, respectively, while the ratio of output and consumption per capita of the main types of products these regions are not even among the top ten leaders (exceptions include potatoes, fruits, berries and grapes in the Chernivtsi region all years, oil in the Lugansk region in 2013), but by certain types of products occupy the last place.

The first place among the regions of Ukraine by the ratio of retail space retail stores to the total population took: in 2012-2013 - Zaporizhzhya region; in 2014 and 2016 - Kyiv region; in 2015 - Odesa region. Zaporizhzhya and Odesa regions fell to a dozen outsiders except for the rating place by the ratio of production and consumption per person of eggs and oils in 2013 in Zaporizhzhya and fruits, berries and grapes in the Odesa region in 2015. According to the indicators of the ratio of 
production and consumption per capita of main types of foodstuffs, Kyiv was among the dozens of leaders excluding potatoes, as well as oils, fruits, berries and grapes in 2016.

According to the results of the assessment of food security rating in 2012, the first three places in the ranking were Chernivtsi, Khmelnytsky and Vinnytsia regions (Table).

Table 1. Rating assessment of food security at the regional level

\begin{tabular}{|c|c|c|c|c|c|c|c|c|c|c|c|c|}
\hline \multirow{3}{*}{$\begin{array}{l}\text { Administrative } \\
\text { region (unit) }\end{array}$} & \multirow{2}{*}{\multicolumn{5}{|c|}{$\begin{array}{l}R_{c p j} \text { (the average arithmetic sum of } \\
\text { regional rankings for all indicators) }\end{array}$}} & & \multicolumn{6}{|c|}{ Region rating } \\
\hline & & & & & & & \multirow{2}{*}{$\frac{N}{8}$} & \multirow{2}{*}{$\stackrel{m}{\frac{n}{\delta}}$} & \multirow{2}{*}{ 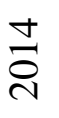 } & \multirow{2}{*}{ 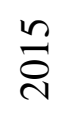 } & \multirow{2}{*}{ 웅 } & \multirow{2}{*}{ 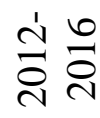 } \\
\hline & 2012 & 2013 & 2014 & 2015 & 2016 & & & & & & & \\
\hline & 0.369 & 0.350 & 0.406 & 0.426 & ח 124 & 0.394 & 3 & 5 & 1 & 1 & 2 & 1 \\
\hline Volyn & 279 & 0.232 & 0.261 & 0.275 & & 0.267 & 13 & 15 & 14 & 13 & 12 & 13 \\
\hline Dnipropetrovsk & 242 & 0.235 & 0.262 & 0.276 & 0.257 & 0.254 & 15 & 13 & 13 & 12 & 15 & 14 \\
\hline Don & 120 & 0.125 & 0.071 & 0.046 & 0.051 & 0.083 & 24 & 24 & 23 & 23 & 23 & 24 \\
\hline & 237 & 0.1 & 0.217 & 0.214 & & .219 & 17 & 19 & 18 & 20 & 18 & 19 \\
\hline Zaka & 342 & 0.284 & 0.315 & 0.318 & 0.291 & 0.310 & 8 & 11 & 10 & 9 & 11 & 9 \\
\hline Zapo & 249 & 0.233 & 0.193 & 0.219 & 0.218 & 0.222 & 14 & 14 & 21 & 19 & 20 & 18 \\
\hline Ivano & 233 & 0.185 & 0.205 & 0.206 & 173 & 0.200 & 18 & 21 & 20 & 22 & 22 & 21 \\
\hline Kyiv & 0.362 & 0.400 & 0.378 & 0.382 & 0.380 & 0.381 & 4 & 1 & 7 & 7 & 6 & 3 \\
\hline & & & & & & & 19 & 20 & 16 & 16 & 8 & 15 \\
\hline & 173 & 0.168 & 0.046 & 0.025 & 0.043 & 0.091 & 23 & 22 & 24 & 24 & 24 & 23 \\
\hline Lviv & 198 & 0.153 & 0.189 & 0.209 & 0.198 & 0.189 & 21 & 23 & 22 & 21 & 21 & 22 \\
\hline Myk & 355 & 0.252 & 0.295 & 0.295 & 0.263 & 0.292 & 5 & 12 & 12 & 11 & 14 & 12 \\
\hline Ode & 241 & 0.215 & & & & 0.230 & 16 & 16 & 19 & 18 & 17 & 17 \\
\hline & 310 & & & & & & 12 & 8 & 8 & 8 & 3 & 8 \\
\hline Rivr & 327 & 0.290 & 0.297 & 0.274 & 0.325 & 0.303 & 10 & 9 & 11 & 14 & 9 & 10 \\
\hline & 205 & & & & & 0.231 & 20 & 17 & 15 & 15 & 16 & 16 \\
\hline Terno & 0.311 & 0.285 & 0.337 & 0.311 & 0.264 & 0.302 & 11 & 10 & 9 & 10 & 13 & 11 \\
\hline & .186 & 0.202 & 0.223 & 0.234 & 0.228 & 0.215 & 22 & 18 & 17 & 17 & 19 & 20 \\
\hline & 0.335 & 0.340 & 0.387 & 0.409 & 0.434 & 0.381 & 9 & 7 & 6 & 3 & 1 & 4 \\
\hline Khmelnits & 0.369 & 0.353 & 0.395 & 0.389 & 0.339 & 0.369 & 2 & 4 & 4 & 5 & 7 & 6 \\
\hline & 0.345 & 0.377 & 0.406 & 0.394 & 0.385 & 0.381 & 7 & 2 & 2 & 4 & 5 & 5 \\
\hline & 0.382 & 0.341 & 0.393 & 0.412 & 0.408 & 0.387 & 1 & 6 & 5 & 2 & 4 & 2 \\
\hline Chernihiv & 0.348 & 0.369 & 0.405 & 0.385 & 0.296 & 0.360 & 6 & 3 & 3 & 6 & 10 & 7 \\
\hline
\end{tabular}

Note: $\mathrm{I}_{\mathrm{j}}$ (average arithmetic sum of regional ratings for 2012-2016)

In 2016, the place of regions in the ranking has changed as follows: in the Chernivtsi and Khmelnytsky regions, the rating has decreased, respectively, by three and five positions, and in the Vinnytsya region, it has increased by one position. Instead, the Kherson and Poltava regions have improved their ranking in eight and nine positions, thus, having received the first and third places in the ranking of food security of the regions in 2016, respectively. The reason for such a significant increase in the ranking was the significant increase in all the partial indicators in Poltava and Kherson (except for the ratio of production and consumption per capita of meat and meat products) regions. 
The stable leadership position of the Vinnytsya region in the top three (with the exception of 2013) provided the region with the first place in the rating on average for the five years studied; Second place in the ranking was Kyiv, and the third - in Chernivtsi region. The third outsider rating for the study period practically did not change: in 2012, 24, 23 and 22 places in the rating took respectively Donetsk, Lugansk and Kharkiv regions; in 2016 - respectively Lugansk, Donetsk and IvanoFrankivsk regions. Thus, in 2016, in comparison with 2012, the Kharkiv region grew in the dynamics in the ranking of three positions (due to the growth of six partial indicators), while Ivano-Frankivsk - fell to four positions (due to a decrease in four partial indicators. In general, the distribution of regions of Ukraine on the food security rating on average in 2012-2016 showed the following (Fig. 2).
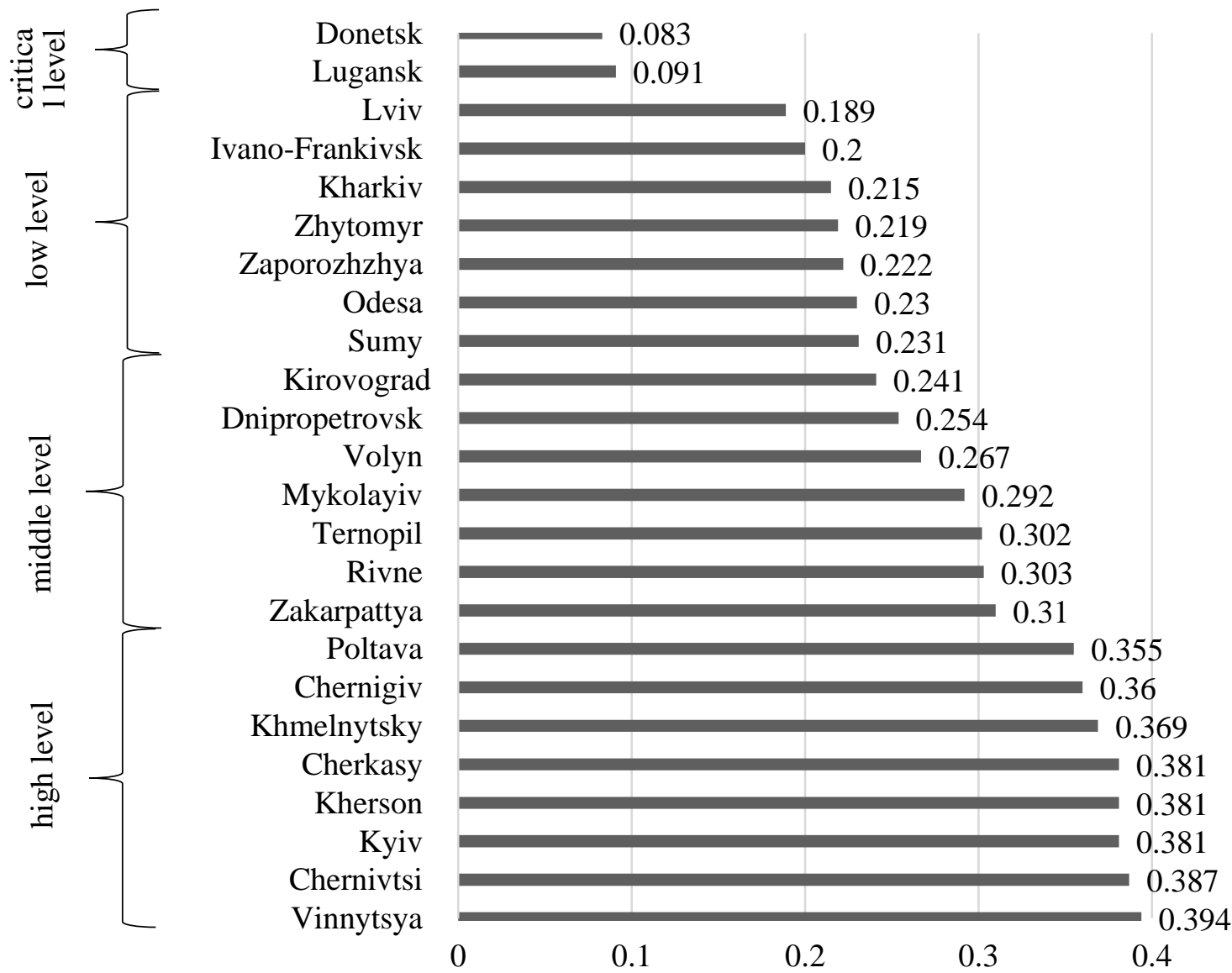

0.5

Figure 2. Rating assessment of food security of regions of Ukraine on average for 2012-2016

Poltava, Chernigiv, Khmelnytsky, Cherkasy, Kherson, Kyiv, Chernivtsi and Vinnytsya regions entered the high-level group; the middle-level group includes Kirovograd, Dnipropetrovsk, Volyn, Mykolayiv, Ternopil, Rivne and Zakarpattya regions; to a low-level group - Lviv, Ivano-Frankivsk, Kharkiv, Zhytomyr, Zaporozhzhya, Odesa and Sumy regions; the critical level is set in Donetsk and Lugansk regions. 


\section{Conclusions}

The authors developed a methodological approach to the food security monitoring and evaluation at the regional level, which includes a rating assessment of the food supply of the regions by the 9 indicators over the last five years (on the average and in the dynamics).

An integrated assessment of the results of food security management at the regional level was carried out in accordance with the criteria and measurements of the GSD-2030. Poltava, Chernigiv, Khmelnytsky, Cherkasy, Kherson, Kyiv, Chernivtsi and Vinnytsya regions entered the high-level group; the middle-level group includes Kirovograd, Dnipropetrovsk, Volyn, Mykolayiv, Ternopil, Rivne and Zakarpattya regions; to a low-level group - Lviv, Ivano-Frankivsk, Kharkiv, Zhytomyr, Zaporozhzhya, Odesa and Sumy regions; the critical level is set in Donetsk and Lugansk regions.

Problems in the field of food security in each particular region are identified. According to the research regions should pay particular attention to ensuring the necessary level of production and consumption per capita ratio: meat and meat products (Zhytomyr, Zaporizhzhya, Mykolayiv, Sumy, Kharkiv and Chernihiv regions), milk and dairy products (Dnipropetrovsk, Donetsk, Zakarpattya, Zapororizhzhya, Ivano-Frankivsk, Kirovograd, Lugansk, Lviv, Mykolayiv, Odesa, Rivne, Ternopil, Kherson and Chervivtsi region); Eggs (Volyn, Dnipropetrovsk, Donetsk, Lugansk, Lviv, Mykolayiv, Odesa and Kharkiv regions); oils (Donetsk, Zhytomyr and Sumy regions); fruits, berries and grapes (Dnipropetrovsk, IvanoFrankivsk and Kirovograd regions), potatoes (Dnipropetrovsk, Donetsk, Zaporizhzhya, Lugansk and Odesa regions); vegetables and food melons (Donetsk, Lugansk and Ivano-Frankivsk regions).

When determining the optimal level of the ratio of the number of trade places in food markets to the total population and retail space retail stores to the total population, the main criterion should be considered the filling of such places selling products by product.

Prospects for further development in this area include the formation of an effective state, regional and local food supply policy based on established problems in the field of food security of each region.

\section{Acknowledgments}

This study is prepared as part of the implementation of the initiative research theme "Food security in terms of European integration of Ukraine" (the state registration number is $0114 \mathrm{U} 007072$ ). This research did not receive any specific grant from funding agencies in the public, commercial, or not-for-profit sectors. 


\section{References}

Babych, M., Kovalenko, A. (2018). Food security Indicators in Ukraine: Current State and Trends of Development // Baltic Journal of Economic Studies. No 4 (1): 8-15.

Bodak, I. (2014). Systemni zakhody rehionalnoi polityky zabezpechennia prodovolchoi bezpeky rehionu // Ekonomichni nauky. No 2: 87-91.

Bytov, V., Hasukha, L. (2013). Indykatory ta kryterii prodovolchoi bezpeky rehionu // Ekonomichnyi forum. No 3: 48-53.

Dziuba, T. (2013). Osoblyvosti formuvannia prodovolchoi bezpeky rehionu // Naukovyi visnyk Natsionalnoho universytetu bioresursiv i pryrodokorystuvannia Ukrainy. No 181(6): 297301.

Kondra, O. (2012). Otsiniuvannia stanu prodovolchoi bezpeky rehionu // Rehionalna ekonomika. No 4: 78-86.

Kotykova O., Babych M. (2019). Limitations in availability of food in Ukraine as a result of loss and waste // Oeconomia Copernicana. 2019. No 10 (1): 153-172.

Kozak, K. (2014). Priorytetni sfery y mekhanizmy zabezpechennia prodovolchoi bezpeky rehioniv // Ekonomika kharchovoi promyslovosti. No 4: 3-9.

National Report "Sustainable Development Goals: Ukraine". https://mfa.gov.ua/mediafiles/sites/poland/files/Sustainable_Development_Goals_Ukraine.pdf [08 05 2019].

Nikishyna, O. (2012). Otsinka stanu prodovolchoi bezpeky Odeskoho rehionu // Ekonomika kharchovoi promyslovosti. No 1: 9-16.

Orlenko, Ya. (2013). Osoblyvosti formuvannia ta realizatsii prodovolchoi bezpeky na rehionalnomu rivni // Investytsii: praktyka ta dosvid. No 12: 134-136.

Piskunova, O., Osypova, O. (2015). Reitynhuvannia rehioniv Ukrainy za rivnem prodovolchoi bezpeky // Formuvannia rynkovykh vidnosyn v Ukraini. No 4: 191-198.

Site of UNU "On Global Sustainable Development Goals". - http://sdg.org.ua/ua/prohlobalni-tsili [08 05 2019].

Shebanina, O., Golubeva, O., Burkovska, A. and Radzevičius, G. (2018). The investment in the meat sector in the context of food security in Ukraine // Managemen Theory and Studies for Rural Business and Infrastructure Development. No 40 (4): 393-402.

Stavytskyi, A., Prokopenko, O. (2014). Otsinka stanu prodovolchoi bezpeky v Ukraini na rehionalnomu rivni // Derzhava ta rehiony. No 2: 41-47.

Ternavska, I. (2010). Intehralna otsinka prodovolchoi bezpeky rehionu // Ahrosvit. No 17: $42-44$

Volchenko, N. (2015). Prodovolcha bezpeka: rehionalnyi aspekt // Visnyk Sumskoho natsionalnoho ahrarnoho universytetu. No 4: 29-33. 